Вісник Національного університету “Львівська політехніка”. Серія "Проблеми економіки та управління"

№ 2(8), 2020

УДК 334.012.61-022.51:330.341.1(477)

JEL Classification Code P12, L64, M21, O30, O31

Kh. P. Danylkiv, N. Ye. Hembarska, O. P. Voloshyn

Lviv Polytechnic National University

\title{
EFFICIENCY OF USING FINANCIAL AND CREDIT INSTRUMENTS TO INTENSIFY THE INNOVATIVE DEVELOPMENT OF SMALL BUSINESS STRUCTURES IN UKRAINE
}

https://doi.org/10.23939/semi2020.02.133

(C) Danylkiv Kh. P., Hembarska N. Ye., Voloshyn O. P., 2020

The article is devoted to substantiation of theoretical and methodical provisions, development of practical recommendations aimed at improving the innovative development of small business structures in the economy of Ukraine using the influence of financial and credit instruments.

The role and importance of small business structures for the Ukrainian economy are revealed, the main problems of its innovative development are covered, including available financial support. The importance of innovative development of small enterprises is noted, in particular their compliance with changes in market conditions, increase and profitability. It is noted that the system of financial support for small businesses should be based on ensuring the smooth flow of innovative development.

The article considers and critically describes the available sources and forms of financial support for small businesses depending on the goals of their activities. In particular, attention is paid to self-financing, equity, public financial support, bank and commercial lending, financial leasing, factoring, forfaiting, financing programs of international financial institutions, grant and venture financing. The most common sources of financial support for the current activities of a small business are its profits and bank lending. At the same time, the possibility of obtaining a bank loan is limited for many reasons. A promising type of financial support for the innovative development of small business structures is venture financing in the form of attracting funds from external investors and grant support from international organizations. Their feature is to provide funds on a non-refundable basis. The conditions of bank lending under the programs of the Ukrainian-German fund are considered in detail.

The peculiarities and substantiation of the main advantages and disadvantages of the existing financial sources of financing are singled out, and also the most effective approaches to financing of innovative activity of small business structures in unfavorable economic conditions are offered.

Key words: financial and credit instruments; innovatively active small business structures; innovative development; state regulation; state support; bank lending; leasing; factoring; forfaiting; credit unions; business centers and business incubators; international support.

\section{Statement of the problem}

Among the regulatory mechanisms, an important role belongs to financial and credit instruments, in particular in the field of innovative development of small business. Small business can rightly be considered as one of the key economic systems, as the need for it is due to the need to ensure socioeconomic stability in the state and production efficiency. 


\section{Kh. P. Danylkiv, N. Ye. Hembarska, O. P. Voloshyn}

In the dynamic development of modern society, the main direction of stimulating economic growth of small businesses is innovative development, which involves the use of fundamentally new advanced technologies, the transition to high-tech products and the development of mechanisms for implementing management decisions in innovation. The current state of the national economy requires intensive innovation, effective organization of the process of research and development, innovation, strategic management in the innovation of each small enterprise. To strengthen their market position and effective innovation, small businesses are forced to seek new sources and forms of investment and form an effective system of measures for their financial and credit support.

The problems of clarifying the role and scientific substantiation of the directions of improvement of innovative development of small business in the economy of Ukraine with the use of financial and credit instruments are actualized. The importance of this task is due to the international experience of market transformations, globalization of economic processes, adaptation to the requirements of post-industrial society and the relatively low share of small business in the national economy.

\section{Analysis of recent research and publications}

A necessary condition for the innovative development of small business structures is the availability of effective financial and credit support, so it is important at the macroeconomic level to develop a comprehensive and effective system of financial and credit support for innovative development of small business in Ukraine.

Analysis of the state of scientific development of this issue in the domestic literature proves that Ukrainian scientists have created a basis for its further study. A significant contribution to the study of small business, its innovative development, placement and financial and credit support was made by T. P. Basiuk, L. P. Davydiuk, Kh. P. Danylkiv, V. Denysiuk, Ya. B. Dropa, M. V. Zaplatynskyi, O. S. Kychuk, A. B. Nemchenko, T. B. Nemchenko, M. Pyvovarov, K. Yu. Skora, I. Ye. Shaidiuk, Yu. I. Cherkasova and others.

At the same time, most components of this field of analysis have room for further research, because existing research requires generalization, consideration of new tools for innovative development and placement of small business in the context of globalization in the Ukrainian economy.

\section{The formulation of objectives}

The purpose of the study is to deepen the theoretical and methodological provisions and develop recommendations for improving the efficiency of financial and credit instruments to enhance the innovative development of small businesses in the context of socio-economic development of Ukraine.

\section{Presentation of main materials}

An important area of sustainable development of modern society is the economic growth of small businesses, in particular, their innovative development, which involves the use of fundamentally new advanced technologies, production of high-tech products and development of mechanisms for implementing management decisions on innovation. Vectors of innovative development of small business in Ukraine today are the intensification of innovation, increasing the efficiency of research and development, innovation, reducing innovation risks, the formation of effective strategies for managing innovation of each small enterprise. That is why, in order to secure their market position and carry out effective innovation activities, small businesses are forced to focus their efforts on finding new sources and forms of investment and a system of measures for its financial and credit support.

The problem of financing the innovative development of enterprises in Ukraine is becoming increasingly important given the increasing competition in both domestic and foreign markets [10, p. 86].

A. Nemchenko interprets the financial support of innovation as a set of methods and instruments for influencing innovation, which is implemented in various forms through the appropriate system of financing $[12$, p. 22]. Thus, the basis for the financial support of innovative activities are measures to attract the necessary amount of funding for innovation in the enterprise, where an important role is played by decisions on the choice of optimal sources and amounts of funding. 
State regulation and support of organic farming in Canada and Ukraine: an overview of key indicators...

Institutional investors who provide financial and credit support to small enterprises are: the state; banking institutions; financial institutions of the non-banking financial sector (credit guarantee institutions, investment, innovation funds, insurance companies, leasing institutions, venture funds), including nonbank institutions, small business self-financing institutions (credit unions, mutual insurance unions, etc.), as well as international organizations and foreign governments opening credit lines [9, p. 163].

It should be noted that self-financing (financing with own funds in terms of net profit and amortization reflections) of investments by small enterprises, significantly narrows the opportunities for expanded reproduction, makes them sensitive to the impact of destructive macroeconomic factors, purchases, etc. and fluctuations in market conditions, which, in turn, reduces their competitiveness in comparison with kpypnym and cepednym vypobnitstvo. The deficit of own funds in the structures of small business has a limiting effect on their innovation policy, blocks the possibility of introducing innovations for the development of production and technological base in the long run. And this, first of all, reduces the cost of scientific and technical research, marketing, staff adaptation. In Ukraine, the total expenditure on research and development (from all sources) over the past 20 years did not exceed $1.3 \%$ of GDP [16]. In general, Ukraine in 2019, according to one of the most authoritative ratings of innovation - the Global Innovation Index, fell to 47th place in the world, while in 2018 it was 43rd [3].

Consider one of the most common traditional ways to support the innovation of small business bank lending, which is an important financial instrument for stimulating and ensuring innovation. Although, according to M. V. Zaplatynskyi, today the banking system of Ukraine does not meet the needs of intensifying the investment and innovation process [10, p. 86]. Small enterprises do not use loans often, and there are reasons for this: a sufficiently high level of interest rates on bank loans, mainly current and short-term nature of bank liabilities, high credit risk, interest rate risk, low liquidity of collateral. Current conditions dictate to banking institutions that they should be the main centers of financing innovation, to issue loans for the production of new products, the development of new technology, the development of new technology. Banks should not issue long-term loans, but should recommend innovations based on alternative projects and business plans, for which it is advisable to take a loan, to act as shareholders with further participation in profits [11, p. 22]. Currently, the NBU is working hard to lend to banks and commercial banks in order to attract borrowers [17].

Small businesses turn their attention to banks that offer more favorable lending terms, in turn, banks choose the most efficient, least risky for lending innovative projects and firms.

An alternative to bank lending may be corporatization. The essence of corporatization, as a type of attracting cash, is the transfer (sale) of some part of the property to another person, cash held by the company remains in its assets, as their return is not provided, but within the contract of corporatization is determined by cash equivalent of dividends to investors, independent sale by the investor of his share of ownership in the property of the enterprise.

As a rule, these are shares that can be sold to another investor or back to the company - the borrower. Entrepreneurs who decide to receive such funds should remember that equity financing involves the participation of the investor in the management of the enterprise [15].

Leasing can be considered a sufficiently widespread method and a powerful impetus for the intensification of innovative entrepreneurial activity, as well as the system of financing the private sector of the economy, as it is associated with certain hopes for solving problems [5, p. 226]. Due to leasing there is a technical re-equipment in traditional industries, increasing the flexibility and efficiency of the economy. The spread of leasing relations reduces the tension associated exclusively with bank financing, stimulates trade in the latest capital goods and technologies [9, p. 168].

Despite the fact that leasing is a completely new service on the Ukrainian market, there has been a noticeable revival of leasing processes recently. Leasing becomes relevant during economic shocks, during the period of production decline, significant unemployment, low purchasing power of the population, which are especially acute in the conditions of quarantine measures related to the coronavirus pandemic COVID-19. 


\section{Kh. P. Danylkiv, N. Ye. Hembarska, O. P. Voloshyn}

We can also highlight another effective means of financing the innovative activities of small businesses in tandem with large - franchising. Franchising is a form of cooperation between legally and financially independent parties, in which one party, which owns a successful business, well-known brand, know-how, trade secrets, reputation and other intangible assets, allows the other party to use this system under certain conditions. Today, franchising is recognized in the world as the most progressive form of doing business. The benefits of franchising are beneficial for entrepreneurs starting their business, as they significantly reduce the risk of failure and loss of funds [4, p. 14].

The opportunity to use already established and justified technologies and equipment, supply services, advertising materials, well-known trademark, to receive constant methodical, technological and informational support and the opportunity to learn and receive consultations in the process of business activity is a great opportunity for business people. Namely, franchising as the most effective business scheme creates favorable and necessary economic preconditions for small business types, allowing to take advantage of all the opportunities of large corporations [7, p. 53-54].

Cooperation with a successful franchisor enables small businesses:

1) become an independent entrepreneur with minimal initial capital investment with the support of an experienced franchisor and a low probability of bankruptcy compared to other small businesses;

2) to obtain open access to credit facilities (commodity, cash);

3) use for a modest fee the results of large-scale advertising activities, scientific research and marketing research conducted by the franchisor.

4) write out the problem of lack of working capital at the initial stages of activity;

5) improve the negotiation process, as banks, leasing companies, other financial and credit organizations cooperate more with franchise system operators than with independent entities, this is due to the fact that in many cases the franchisor can act as financial guarantor for the franchisee of its system;

6) to produce competitive products, because competition within one franchise system, as a rule, is absent;

7) use the system already established by the franchisor to conduct market research and collect the necessary complete and reliable information about the state and trends of market development;

8) to acquire special knowledge from the franchisor through training and professional advice on business management, to acquire skills in accordance with high quality standards, which will avoid difficulties in selecting reliable business partners;

9) get a ready market niche, using the trademark, symbols, logos, trade name, methods of exterior and interior design of production facilities and business reputation of the franchisor.

As you can see, the role of franchising in improving the efficiency of innovative development of small businesses is significant.

The next form of lending for scientific and technical activities, which we can recommend to small businesses is forfaiting. Forfaiting is the transaction by a financial agent called a forfeiter of a commercial obligation of a borrower, which is a buyer/importer, to a lender (seller/exporter). This operation is a specific form of trade credit. The main condition for forfeiting is that all the risks of debt obligations pass to the forfeiter without the right to return to the seller's obligations [1, p. 21]. For the investor, forfaiting is a very expensive form of lending.

Note that in Ukraine the forfaiting market is not yet perfect and underdeveloped, and, as a rule, is medium-term in nature and is intended for exporters of goods: machinery, vehicles and equipment, capital services (construction of industrial and infrastructure facilities abroad), solutions in the field of information technology. We see the reason for this in a number of legislative restrictions that do not allow banks to act as forfeiters, the lack of experience in banks under forfeiting schemes.

The above difficulties can be overcome by such a financial instrument as factoring, which is best suited for current processes of small business development.

The main task of factoring is to organize the supplier's relationship with customers so that the supplier can provide significant payment delays without experiencing a shortage of working capital. 
State regulation and support of organic farming in Canada and Ukraine: an overview of key indicators...

Factoring can be used by small businesses as a powerful tool to maintain a competitive market position. With it, small businesses can increase sales, customer numbers and competitiveness by giving customers a reprieve. One of the main advantages of this service is obtaining a loan of up to $90 \%$ of the value of the delivered goods, which will significantly speed up the turnover of funds. In turn, the buyer has the opportunity to obtain a commodity loan, increase the volume of purchases and thus improve competitiveness.

In our opinion, the reason for this is the intensification of the struggle in the market of factoring services between banking institutions that are actively developing this type of business and factoring companies. The struggle is also exacerbated by the fact that, in contrast to previous years, when banks served mainly large and medium-sized businesses, now banking institutions have begun to actively cooperate with small businesses. It should also be noted that banking institutions have a significant advantage - the presence of a significant number of credit institutions and the ability to provide customers with hybrid products without collateral financing, which in turn combine factoring operations and other banking services. However, the advantage of factoring companies is the lower cost of providing services and greater flexibility and efficiency in decision-making.

Thus, factoring is a particularly profitable form of financing for small businesses, which allows management and employees to focus on production problems and maximize profits, accelerates the receipt of most payments and ensures full repayment of debts and reduces costs.

Venture financing is a promising tool for financial support of innovative development of a small enterprise. Venture financing is one of the most effective ways of financing venture capital by private business entities engaged in risky research and development [9, p. 167]. The purpose of this funding is to promote the growth of innovative business with the help of financial support from relevant organizations, and the emphasis will be not only on increasing the funds invested, but also on the innovative development of small businesses.

The main difference from traditional investing is that financial assets are provided to the company without any guarantee of security or non-financial assets or savings of small businesses. The only guarantee is the relevant part of the shares (less than the controlling stake) of the existing or only the created enterprise, ie the wedding capital is provided to the enterprise under a promising idea.

Specific features of venture financing are:

s the presence of direct or indirect equity participation of the investor in the company's capital;

, providing funds for a long period on a non-refundable (interest-free) basis;

, lack of guarantees or security from the venture;

- there is a significant risk, which is offset by the possibility of obtaining excess profits;

- active field of the investor in the management of the funded project.

The development of the venture sector is especially relevant because the main areas of use of venture capital are high and new technologies that will increase employment and living standards. However, the increase in venture financing in our country can not be called satisfactory. Ukraine has its own sources of urgent lending to small businesses. Ukrainian banks are not exposed to risk and do not participate in venture capital companies. In Western Europe, on the other hand, banks, pension funds and insurance companies account for almost two-thirds of all venture capital.

It should be noted that in developed countries, insurance companies and pension funds are active participants in the development of innovative small businesses. These financial intermediaries are the subjects of the financial and credit system, which ensure the accumulation of savings of individual investors and the transfer of funds from creditors to borrowers [20, p. 328].

In Ukraine, the function of insurance companies and private pension funds as a financial source of innovation in small business remains unrealized. Therefore, the state must create real opportunities for institutional investors to provide funds for innovative projects, especially for small businesses.

Another market mechanism for alternative financing of innovation activities of small businesses are credit unions - financial institutions whose activities are to meet the needs of their members in mutual 


\section{Kh. P. Danylkiv, N. Ye. Hembarska, O. P. Voloshyn}

lending and the provision of other financial services through their combined cash contributions. Compared to commercial banks, credit unions are interested in dealing with small loans and taking into account the small financial problems of entrepreneurs.

Here are the main advantages of credit unions for small business financing:

1) their maximum proximity to the direct recipients of services;

2) the possibility of the borrower under the simplified scheme to obtain a loan even in small amounts;

3) use to compensate for expenses and risks when issuing small loans lower interest rates and less stringent conditions to ensure the fulfillment of obligations;

4) special opportunities for financing the development of agricultural producers who are members of such credit unions.

Due to their philosophy, credit unions around the world play an important role in increasing the availability of financial services to the general population and the level of its financial literacy and is an effective tool for increasing the economic well-being of the population [2, p. 4].

The concept of a new model of credit union regulation, proposed by the National Bank of Ukraine in March 2020, provides for the following consequences of its implementation:

, deeper penetration of credit unions into the financial services market by expanding the list of services and products, as well as the possibility of providing them on more favorable terms;

, increasing the level of capitalization and stress resilience of credit unions and, as a consequence, strengthening the reliability of the sector and consumer confidence in it;

, increasing the level of availability of financial services for the general public and small businesses, especially in remote and rural areas;

, uniform high standards of consumer protection, which will apply to members of credit unions on an equal footing with other financial institutions;

strengthening the cooperation of credit unions with territorial communities in order to support the implementation of regional programs of social and economic development of the respective territories [2, p. 25].

It is worth noting that the solution of the problem of special support of small innovative business is directly related to the development of its infrastructure, the main tasks of which are to direct market specific flows to the implementation of innovative projects and promote market adaptation of innovative enterprises. Attention has been paid to the development of business infrastructure in various legislative and regulatory acts in recent years: Laws of Ukraine "On the Principles of State Regional Policy"; "On the development and state support of small and medium enterprises in Ukraine"; "Sustainable Development Strategy" Ukraine 2020"; "State strategy for regional development until 2020". However, at the moment the institutional basis of the business infrastructure has not been formed, there is no effective state support for small business.

Infrastructure to support small and medium enterprises are enterprises, institutions and organizations, regardless of ownership, that carry out activities aimed at the development of small and medium enterprises, their investment and innovation activities, promotion of their products, works, services, intellectual activities on domestic and foreign markets [18].

World practice shows that such innovative structures as technoparks, technopolises, business incubators, scientific and scientific-technological packs, which specialize in creating favorable conditions for effective innovative activity of small technical enterprises, are effective. The main purpose of such structures is to assist small innovative enterprises by providing them with temporary use of production areas, material and technical base, information networks, providing research instruments and equipment and providing advisory assistance on a wide range of scientific, technological, economic and legal issues [21, p. 359-360].

Business incubators are potential sources of advanced technologies to support the innovative development of a small enterprise. They are the opportunities that encourage the development of innovation 
State regulation and support of organic farming in Canada and Ukraine: an overview of key indicators...

processes among representatives of small businesses and at the same time are an instrument of economic, social, structural and innovation policy.

The organizational structure of business incubators is focused on quality services by small innovation entities, as their success directly depends on the fact that small innovation structures become profitable as soon as possible, which guarantees the business incubator a significant share in their future profits. They have the opportunity to conduct expertise of innovative projects, patent research, search for investors, insure and guarantee the protection of small business structures [12, p. 40].

The main goals and objectives of the business incubator are to support, create and implement new technologies and information systems that are competitive in the world market, to promote the creation, establishment and development of small innovative enterprises by providing them with training and consulting and consulting [19, p. 12].

A relatively new institution for supporting small business are business centers, whose functions are to provide support in the form of advisory assistance, training and retraining for small business. Business centers are institutions that provide information, consulting, marketing, training and other services to businesses and individuals who wish to engage in entrepreneurial activities. Business centers can provide facilities for business meetings, communications, computers and electronics. The range of services in different business centers varies considerably. Unlike business incubators, business centers provide services, usually to individuals and at commercial rates [14].

Today, the most noteworthy are those business centers and business incubators, whose main tasks are to create conditions for the establishment of small business and the creation of new jobs in the sector of small manufacturing, innovative enterprises. As well as those who work in the following areas: training, retraining and advanced training; conducting marketing research; information support; consulting services; assistance in registration of enterprises; legal services; audit services; provision of official and production premises for rent (on preferential terms); provision of office services (multiplication of materials, provision of communications, equipment, etc.); assistance in obtaining investments and loans; leasing of equipment; product advertising, etc. [13].

In modern conditions, the most effective form of integration of innovations into production is the creation of organizational and economic conditions and opportunities in "scientific and technological folders" for simultaneous formation, in order to commercialize the results of research, on the basis of numerous small universities. The main issue of formation and functioning of these structures is the search for sources of funding.

The task of technology parks is not only to stimulate the formation and development of new small innovative business structures using the results of scientific research of university, academic and other research centers, but also, most importantly, to create conditions for these enterprises that would allow them to spend more time. to carry out all stages of the cycle of transfer of scientific knowledge into the material sphere, promotion of technology transfer [8].

The most consolidated structural unit among other innovative forms of doing business is technopolis, which is a large-scale scientific and industrial complex with advanced infrastructure of the service sector, focused on the creation, support and development of commercial and commercial facilities enterprises in the field of high technologies.

International support will make a significant contribution to the formation and innovative development of small business in Ukraine. It significantly complements and compensates for state support measures, especially financial ones. Most modern assistance programs consist of the following main areas: financial the allocation of loans, grants; information-advisory - consulting on various issues of doing business and providing the necessary business information; training of entrepreneurs in the basics of the market economy, methods of international accounting.

Today there are several credit lines in Ukraine. The terms of borrowing are quite similar: they are the same in terms of collateral requirements and business plans and differ in interest rates and loan rates. However, given the conditions of international financing, very few domestic small innovative enterprises 


\section{Kh. P. Danylkiv, N. Ye. Hembarska, O. P. Voloshyn}

can use their loans. Funding funds are very limited, and most small businesses are unable to provide valuable collateral and meet other creditors' requirements.

Investments of international funds in the development of Ukrainian small business are 3-7 times less than in Central and Eastern Europe. This situation is due to the high degree of investment risk in the country. According to the level of freedom of business, Ukraine has one of the lowest ratings among European countries.

International support for the innovative development of small business in Ukraine is an important factor in the growth of the private sector in the country, the establishment of a market economy and freedom of enterprise. Of course, not all small businesses can still get it. However, it is important that with each passing year, the volume of international aid increases, which is reflected in the emergence of new business centers and the expansion of credit lines. In conditions when the state is not able to fully support its small business sector, the initiative was taken by foreign and domestic structures, which already have examples of successful cooperation with small entrepreneurs.

An extremely important issue is improving access to external sources of financing, creating favorable conditions for attracting foreign capital in the field of small innovative entrepreneurship, which involves the creation and support of regional business centers, business incubators, technology parks, etc., and the formation of financial markets. and innovation funds.

\section{Conclusions}

Ensuring a favorable development of domestic small business, intensification of its innovative orientation is possible only if the financial constraints in which Ukraine's economy finds itself today are overcome.

Particularly acute are the problems of insufficient own funds of enterprises to ensure stable operations, as well as the insufficient level of capitalization of the banking sector, which limits the ability to finance long-term investment projects in the small business sector. The lack of sufficient financial support for small business structures is the main reason for the slowdown in the dynamic development of this sector of domestic entrepreneurship in today's Ukraine. In modern conditions, it is impossible to provide financing for innovative changes only through the budget system or the banking sector. To create a holistic system that will provide adequate support for the development of small businesses and its innovative focus with the necessary funds, you need a "mixed" model of their financing, which includes state support for the development of specialized banking credit institutions, non-bank financial investors, private investors. states in methodological and legal support.

\section{Prospects for further research}

We see in the study of issues of support for small businesses in countries with post-industrial development.

1. Басюк Т. П. (2020). Фінансові аспекти зовнішньоекономічних операцій. Економіка, фінанси, право, № 6, C. 20-24.

2. Біла книга (2020). Майбутне регулювання кредитних спілок. НБУ. Київ. Available at: https://bank.gov.ua/admin_uploads/article/White_paper_KS_2020.pdf?v=4.

3. Глобальний інноваційний індекс (2019). Available at: www.wipo.int/edocs/pubdocs/ en/wipo_pub_gii_2019.pdf.

4. Давидюк Л. П. (2019). Розвиток франчайзингового бізнесу в Україні та світі. Причорноморські економічні студіï: наук. журнал, Вип. 46 (частина 1), С. 13-19.

5. Данилків Х. П. (2012). Лізингові послуги як перспективна форма розвитку малих підприємницьких структур. Фінансово-економічні проблеми сучасного світу: шляхи і перспективи їх вирішення на мікро-, макро- та мегарівнях: Всеукр. наук.-практ. конф. студентів, аспірантів і молодих вчених 24 лютого 2012 p. Кременчук, С. 225-227.

6. Данилків Х. (2012). Фінансово-кредитна підтримка малого підприємництва в Україні. Розвиток економіки Украӥни в умовах активізації євроінтеграційних процесів: міжнар. студент.-аспір. конф., 2728 квітня 2012 р. Львів, С. 91-93.

7. Данылкив К. П. (2013). Франчайзинг как альтернатива для развития малого бизнеса в Украине. Финансовая аналитика: науч.-практ. и информ.-аналит. сб. М., № 44(182), С. 52-57. 
State regulation and support of organic farming in Canada and Ukraine: an overview of key indicators...

8. Денисюк В. Розвиток інноваційних територіальних структур як важливої складової української інноваційної системи. Інтернет-холдинг Олега Соскіна. Available at: http://soskin.info/ea/2003/7-8/20030712.html.

9. Дропа Я. Б., Данилків Х. П. (2011). Основні джерела фінансово-кредитного розвитку малого підприємництва. Економічний простір, № 52/2, С. 161-173.

10. Заплатинський М. В. (2020). Проблеми фінансового забезпечення інноваційної діяльності підприємств в Україні. Агросвіт, № 4, С. 83-90.

11. Кичук О. С. (2009). Организационно-экономический механизм содействия развитию малого предпринимательства: дис. ... канд. екон. наук: 08.00.04. Одесса, 226 с.

12. Немченко А. Б., Немченко Т. Б. (2010). Бізнес-інкубатори в сфері сучасної державної підтримки розвитку регіональної інноваційної інфраструктури. Економічні науки, Вип. 17, С. 36-42.

13. Офіційний сайт Американської адміністрації малого бізнесу (U. S. Small Business Administration). Available at: http://www.sba.gov.

14. Офіційний сайт Аналітичного центру “Академія”. Available at: http://www.academia.org.ua/?p=274.

15. Офіційний сайт Державного комітету 3 питань регуляторної політики та підприємництва. Узагальнені звіти про стан виконання регіональних програм розвитку малого підприємництва в Україні. Available at: http://www.dkrp.gov.ua.

16. Офіційний сайт Державної служби статистики України. Available at: http://ukrstat.gov.ua.

17. Офіційний сайт Національного банку України. Available at: http://www.bank.gov.ua.

18. Про розвиток та державну підтримку малого і середнього підприємництва в Україні: Закон України № 4618-VI від 22.03.12 p. Available at: https://zakon.rada.gov.ua/laws/show/4618-17.

19. Пивоваров М. (2013). Розвиток інституту інфраструктури малого підприємництва: проблеми та шляхи його покращення. Соціально-економічні проблеми і держава, Вип. 1(8), С. 6-18.

20. Скора К. Ю. (2007). Джерела фінансування малого підприємництва в Україні. Держава та регіони. Серія: Економіка та підприємництва, № 2, С. 326-330.

21. Шайдюк I. Є., Черкасова Ю. І. (2010). Проблеми та перспективи розвитку інноваційної діяльності малих підприємств в Україні. Бюлетень міжнародного Нобелівського економічного форуму, № 1(3), Т. 2, С. 357-362.

1. Basiuk T. P. (2020). Finansovi aspekty zovnishnoekonomichnykh operatsii [Financial aspects of foreign economic operations]. Ekonomika, finansy, parvo [Economics, finance, law], No. 6, pp. 20-24. (in Ukrainian).

2. Bila knyha (2020). Maibutnie rehuliuvannia kredytnykh spilok. NBU. Kyiv [Future regulation of credit unions. NBU. Kiev]. Retrieved from: https://bank.gov.ua/admin_uploads/article/White_paper_KS_2020.pdf?v=4 (in Ukrainian).

3. Hlobalnyi innovatsiinyi indeks (2019). URL: www.wipo.int/edocs/pubdocs/en/wipo_pub_gii_2019.pdf. (in Ukrainian).

4. Davydiuk L. P. (2019). Rozvytok franchaizynhovoho biznesu v Ukraini ta sviti [Development of franchising business in Ukraine and the world]. Prychornomorski ekonomichni studii [Black Sea Economic Studies], No. 46(1), pp. 13-19. (in Ukrainian).

5. Danylkiv Kh. P. (2012). Lizynhovi posluhy yak perspektyvna forma rozvytku malykh pidpryiemnytskykh struktur [Leasing services as a promising form of development of small business structures]. Finansovo-ekonomichni problemy suchasnoho svitu: shliakhy i perspektyvy yikh vyrishennia na mikro-, makro- ta meharivniakh: Vseukr. nauk.-prakt. konf. studentiv, aspirantiv i molodykh vchenykh [Financial and economic problems of the modern world: ways and prospects for their solution at the micro, macro and mega levels: all-Ukrainian. scientific-practical conf. students, graduate students and young scientists], pp. 225-227. (in Ukrainian).

6. Danylkiv Kh. (2012). Finansovo-kredytna pidtrymka maloho pidpryiemnytstva v Ukraini [Financial and credit support for small business in Ukraine]. Rozvytok ekonomiky Ukrainy v umovakh aktyvizatsii yevrointehratsiinykh protsesiv: mizhnar. studentsko-aspirantskoi konf. [Development of Ukraine's economy in terms of intensification of European integration processes: int. student-graduate conference]. Lviv, pp. 91-93. (in Ukrainian).

7. Danylkiv K. P. (2013). Franchaizynh kak alternatyva dlia razvytyia maloho byznesa v Ukrayne [Franchising as an alternative for small business development in Ukraine]. Fynansovaia analytyka: nauch.-prakt. y ynform.-analyt. sb. [Financial analytics: scientific-practical. and inform.-analyst. sat], No. 44(182), pp. $52-57$.

8. Denysiuk V. Rozvytok innovatsiinykh terytorialnykh struktur yak vazhlyvoi skladovoi ukrainskoi innovatsiinoi systemy [Development of innovative territorial structures as an important component of the Ukrainian innovation system]. Internet-kholdynh Oleha Soskina [Oleg Soskin Internet Holding]. Retrieved from: http://soskin.info/ea/2003/7-8/20030712.html. (in Ukrainian). 
9. Dropa Ya. B. (2011). Osnovni dzherela finansovo-kredytnoho rozvytku maloho pidpryiemnytstva [The main sources of financial and credit development of small business]. Ekonomichnyi prostir [Economic space], No. 52/2, pp. 161-173. (in Ukrainian).

10. Zaplatynskyi M. V. (2020). Problemy finansovoho zabezpechennia innovatsiinoi diialnosti pidpryiemstv v Ukraini [Problems of financial support of innovative activity of enterprises in Ukraine]. Ahrosvit [Agrosvit], No. 4, pp. 83-90. (in Ukrainian).

11. Kychuk O. S. (2009). Orhanyzatsyonno-эkonomycheskyi mekhanyzm sodeistvyia razvytyiu maloho predprynymatelstva [Organizational and economic mechanism to promote the development of small business]. Dys. ... kand. ekon. nauk: 08.00.04 [dis. ... cand. econ. sciences: 08.00.04]. Odessa, 226 s. (in Ukrainian).

12. Nemchenko A. B., Nemchenko T. B. (2010). Biznes-inkubatory v sferi suchasnoi derzhavnoi pidtrymky rozvytku rehionalnoi innovatsiinoi infrastruktury [Business incubators in the field of modern state support for the development of regional innovation infrastructure]. Ekonomichni nauky [Economic Sciences], No. 17, pp. 36-42. (in Ukrainian).

13. Ofitsiinyi sait Amerykanskoi Administratsii maloho biznesu (U. S. Small Business Administration) [Official website of the US Small Business Administration Access mode]. Retrieved from: http://www.sba.gov.

14. Ofitsiinyi sait Analitychnoho tsentru "Akademiia" [Official site of the Analytical Center "Academy"]. Retrieved from: http://www.academia.org.ua/?p=274.

15. Ofitsiinyi sait Derzhavnoho komitetu z pytan rehuliatornoi polityky ta pidpryiemnytstva. Uzahalneni zvity pro stan vykonannia rehionalnykh prohram rozvytku maloho pidpryiemnytstva v Ukraini [Official site of the State Committee for Regulatory Policy and Entrepreneurship. Generalized reports on the state of implementation of regional small business development programs in Ukraine]. Retrieved from: http://www.dkrp.gov.ua. (in Ukrainian).

16. Ofitsiinyi sait Derzhavnoi sluzhby statystyky Ukrainy [Official site of the State Statistics Service of Ukraine]. Retrieved from: http://ukrstat.gov.ua (in Ukrainian).

17. Ofitsiinyi sait Natsionalnoho Banku Ukrainy [Official website of the National Bank of Ukraine]. Retrieved from: http://www.bank.gov.ua (in Ukrainian).

18. Pro rozvytok ta derzhavnu pidtrymku maloho i serednoho pidpryiemnytstva $v$ Ukraini [On the development and state support of small and medium enterprises in Ukraine]. Zakon Ukrainy [Law of Ukraine], No. 4618-VI vid 22.03.12 r. Retrieved from: https://zakon.rada.gov.ua/laws/show/4618-17. (in Ukrainian).

19. Pyvovarov M. (2013). Rozvytok instytutu infrastruktury maloho pidpryiemnytstva: problemy ta shliakhy yoho pokrashchennia [Development of the institute of small business infrastructure: problems and ways to improve it]. Sotsialno-ekonomichni problemy $i$ derzhava [Socio-economic problems and the state], No. 1(8), pp. 6-18. (in Ukrainian).

20. Skora K. Yu. (2007). Dzherela finansuvannia maloho pidpryiemnytstva v Ukraini [Sources of small business financing in Ukraine]. Derzhava ta rehiony. Seriia: Ekonomika ta pidpryiemnytstva [State and Regions. Series: Economics and Entrepreneurship], No. 2, pp. 326-330. (in Ukrainian).

21. Shaidiuk I. Ye., Cherkasova Yu. I. (2010). Problemy ta perspektyvy rozvytku innovatsiinoi diialnosti malykh pidpryiemstv v Ukraini [Problems and prospects of development of innovative activity of small enterprises in Ukraine]. Biuleten mizhnarodnoho Nobyluvskoho ekonomichnoho forumu [Bulletin of the International Nobel Economic Forum], No. 1(3), Tom 2, pp. 357-362. (in Ukrainian).

Х. П. Данилків, Н. Є. Гембарська, О. П. Волошин Національний університет "Львівська політехніка", кафедра фінансів, обліку і аналізу

\title{
ЕФЕКТИВНІСТЬ ВИКОРИСТАННЯ ФІНАНСОВО-КРЕДИТНИХ ІНСТРУМЕНТІВ АКТИВІЗАЦЇ̈ ІННОВАЦЙНОГО РОЗВИТКУ МАЛИХ ПІДПРИСМНИЦЬКИХ СТРУКТУР В УКРАЇНІ
}

\author{
(C) Данилків Х. П., Гембарська Н. Є., Волочин О. П., 2020
}

Обгрунтовано теоретичні й методичні положення, розроблено практичні рекомендації, спрямовані на удосконалення інноваційного розвитку малих підприємницьких структур в економіці України із застосуванням впливу фінансово-кредитних інструментів.

Розкрито роль та значення малих підприсмницьких структур для української економіки, висвітлено основні проблеми їхнього інноваційного розвитку, зокрема доступну фінансову підтримку. Відзначено важливість інноваційного розвитку малих підприємств, зокрема їх від- 
State regulation and support of organic farming in Canada and Ukraine: an overview of key indicators...

повідність змінам ринкових умов, збільшенню та прибутковості. Зазначено, що система фінансової підтримки діяльності суб'сктів малого підприсмництва повинна будуватися на забезпеченні безперебійного поточного інноваційного розвитку.

У статті розглянуто та критично описано наявні джерела та форми фінансової підтримки малих підприсмницьких структур залежно від цілей їхньої діяльності. Зокрема, увагу звернено на самофінансування, власний капітал, державну фінансову підтримку, банківське та комерційне кредитування, фінансовий лізинг, факторинг, форфейтинг, програми фінансування міжнародних фінансових установ, грантове та венчурне фінансування. Найпоширеніші джерела фінансової підтримки поточної діяльності малого підприсмства - його прибуток та банківське кредитування. Водночас можливість отримання банківської позики обмежена з багатьох причин. Перспективним видом фінансової підтримки інноваційного розвитку малих підприємницьких структур є венчурне фінансування у формі залучення коштів зовнішнього інвестора та грантової підтримки міжнародних організацій. Їх особливість полягає у наданні коштів на безповоротній основі. Детально розглянуто умови банківського кредитування за програмами українськонімецького фонду.

Виділено особливості та обгрунтовано основні переваги та недоліки наявних фінансових джерел фінансування, а також запропоновано найефективніші підходи до фінансування інноваційної діяльності малих підприємницьких структур у несприятливих економічних умовах.

Ключові слова: фінансово-кредитні інструменти; інноваційно активні малі підприсмницькі структури; інноваційний розвиток; державне регулювання; державна підтримка; банківське кредитування; лізинг; факторинг; форфейтинг; кредитні спілки; бізнес-центри та бізнес-інкубатори; міжнародна підтримка. 